Is It Safe? 
This page intentionally left blank 


\section{Is It Safe?}

BPA and the Struggle to Define the Safety of Chemicals

SARAH A. VOGEL

甲

University of California Press

BERKELEY LOS ANGELES LONDON 
University of California Press, one of the most distinguished university presses in the United States, enriches lives around the world by advancing scholarship in the humanities, social sciences, and natural sciences. Its activities are supported by the UC Press Foundation and by philanthropic contributions from individuals and institutions. For more information, visit www.ucpress.edu.

University of California Press

Berkeley and Los Angeles, California

University of California Press, Ltd.

London, England

(C) 2013 by The Regents of the University of California

Library of Congress Cataloging-in-Publication Data

Vogel, Sarah A. (Sarah Ann), 1974-

Is it safe? : BPA and the struggle to define the safety of chemicals / Sarah A. Vogel.

p. $\mathrm{cm}$.

Includes bibliographical references and index.

ISBN 978-0-520-27357-3 (cloth : alk. paper)—ISBN 978-0-520-27358-o (pbk. : alk. paper)

I. Title.

[DNLM: 1. Phenols-toxicity. 2. Economics. 3. Endocrine Disruptors-toxicity. 4. Environmental Exposure-legislation \& jurisprudence. 5. Environmental Exposure-standards. 6. Politics. QV 627]

$615.9^{\prime} 5131-\mathrm{dc} 23$

2012026476

Manufactured in the United States of America

$\begin{array}{llllllll}20 & 19 & 18 & 17 & 16 & 15 & 14 & 13\end{array}$

$\begin{array}{llllllllll}10 & 9 & 8 & 7 & 6 & 5 & 4 & 3 & 2 & 1\end{array}$

In keeping with a commitment to support environmentally responsible and sustainable printing practices, UC Press has printed this book on 50-pound Enterprise, a 30\% post-consumer-waste, recycled, deinked fiber that is processed chlorine-free. It is acid-free and meets all ANSI/NISO ( $\mathrm{z}$ 39.48) requirements. 
In memory of my mother, Judy Vogel 
This page intentionally left blank 